\title{
Fitness and Competitive Ability of Botrytis cinerea Isolates with Resistance to Multiple Chemical Classes of Fungicides
}

\author{
S. N. Chen, C. X. Luo, M. J. Hu, and G. Schnabel
}

First and second authors: Huazhong Agricultural University, College of Plant Science and Technology, Wuhan 430070, China; and third and fourth authors: Clemson University, Department of Agricultural and Environmental Sciences, Clemson, SC 29634. Accepted for publication 3 May 2016.

\begin{abstract}
Chen, S. N., Luo, C. X., Hu, M. J., and Schnabel, G. 2016. Fitness and competitive ability of Botrytis cinerea isolates with resistance to multiple chemical classes of fungicides. Phytopathology 106:997-1005.

Resistance to multiple chemical classes of fungicides in Botrytis cinerea isolates from eastern United States strawberry fields is common and strategies to control them are needed. In this study, we compared fitness and competitive ability of eight sensitive isolates (S), eight isolates resistant to five or six chemical classes of fungicides but not to phenylpyrroles (5CCR), and eight isolates resistant to six or seven chemical classes including phenylpyrroles (6CCR/MDR1h). The latter included the MDR1h phenotype due to overexpression of atrB based on $\Delta 497 \mathrm{~V} / \mathrm{L}$ in $\mathrm{mrrl}$. The 6CCR/MDR1h

isolates grew more slowly at $4^{\circ} \mathrm{C}$ on potato dextrose agar, and both $5 \mathrm{CCR}$ and 6CCR/MDR1h isolates were hypersensitive to osmotic stress compared with $\mathrm{S}$ isolates. In contrast, no differences were found in oxidative sensitivity, aggressiveness, and spore production in vivo, and sclerotia production and viability in vitro. In competition experiments, the 5CCR and 6CCR/MDR1h isolates were both outcompeted by $\mathrm{S}$ isolates and 6CCR/MDR1h isolates were outcompeted by 5CCR isolates in the absence of fungicide pressure. Under selective pressure of a fludioxonil/pyraclostrobin rotation, the 6CCR/ MDR1h isolates dominated after coinoculation with 5CCR and S isolates. The competitive disadvantage of $5 \mathrm{CCR}$ and especially 6CCR/MDR $1 \mathrm{~h}$ isolates suggest that, in the absence of fungicide selection pressure, $S$ isolates may reduce inoculum potential of multifungicide-resistant isolates under field conditions.
\end{abstract}

Botrytis cinerea Pers. (teleomorph Botryotinia fuckeliana) is the causal agent of gray mold of more than 200 plant species and represents a high risk for development of resistance to fungicides. Although cultural methods such as appropriate plant spacing and fertilization can reduce disease incidence, fungicide applications are still the key to disease management. Site-specific fungicides used for gray mold control belong to Fungicide Resistance Action Committee (FRAC) codes 1, 2, 7, 9, 11, 12, and 17, representing methyl benzimidazole carbamates, dicarboximides, succinate dehydrogenase inhibitors (SDHI), anilinopyrimidines, quinone outside inhibitors, phenylpyrroles, and sterol biosynthesis inhibitor class III fungicide hydroxyanilide, respectively. Multisite inhibitors such as captan and thiram (FRAC codes M3 and M4, respectively) are also frequently used alone or in tank mixtures with site-specific fungicides.

Botrytis cinerea isolates with resistance to multiple fungicides are found in commercial strawberry and blackberry fields of Germany (Hahn et al. 2014; Leroch et al. 2013; Weber 2011), the United States (Amiri et al. 2012; Fernández-Ortuño et al. 2014, 2015; Li et al. 2014a), Israel (Elad et al. 1992), Spain (Raposo et al. 1996), and Chile (Latorre and Torres 2012), as well as from kiwi fields in Greece (Bardas et al. 2010). In South Carolina and other eastern states, B. cinerea isolates from strawberry fields with widespread resistance to five fungicides of different chemical classes (5CCR), including boscalid, pyraclostrobin, fenhexamid, cyprodinil, and pyrimethanil, have been reported (Amiri et al. 2013; Fernández-Ortuño et al. 2015). Resistance to multiple FRAC groups is mostly conferred via the accumulation of point mutations in target genes over time ( $\mathrm{Li}$ et al. 2014a). However, B. cinerea populations with a single mechanism conferring resistance to multiple fungicides were identified previously. Resistance was based on increased activity of drug efflux pumps, designated the multidrug-

Corresponding author: G. Schnabel; E-mail address: schnabe@clemson.edu resistant (MDR) phenotype. MDR isolates were reported in French and German vineyards (Kretschmer et al. 2009; Leroch et al. 2011) and small fruit fields in Virginia and South Carolina (FernándezOrtuño et al. 2015). MDR1 isolates overexpress the ATP transporter gene $a t r B$, which makes them partially resistant to fludioxonil, cyprodinil, and tolnaftate (Kretschmer et al. 2009). A variant of the MDR1 phenotype, MDR1h, was subsequently identified in German strawberry fields (Leroch et al. 2013). Compared with MDR1 isolates, the expression of $a t r B$ was higher in MDR1h isolates and resulted in higher levels of resistance to fludioxonil and cyprodinil (FernándezOrtuño et al. 2015). The MDR1h phenotype was recently confirmed in the United States in isolates from blackberry in Georgia and isolates from strawberry in Connecticut (Fernández-Ortuño et al. 2015) but very little is known about these isolates with regard to fitness and competitiveness. Such information will help assess the establishment and dynamics of fungicide resistance frequencies in the pathogen population (Chin et al. 2001; Parnell et al. 2005).

In a previous study, a limited number of fitness characteristics were investigated for three MDR1 and three MDR1h phenotypes. Data showed that multifungicide-resistant MDR1h isolates were not impaired in their ability to grow on multiple different media at different temperatures but may be significantly more sensitive to salt stress (Fernández-Ortuño et al. 2015). The objective of this study was to more thoroughly investigate fitness parameters with more isolates and to determine competitiveness of eight sensitive isolates ( $\mathrm{S}$ isolates), eight isolates resistant to five or six chemical classes of fungicides from different chemical classes except the phenylpyrroles (5CCR isolates), and eight isolates resistant to at least six chemical classes including the phenylpyrroles (6CCR/MDR1h isolates).

\section{MATERIALS AND METHODS}

Fungal isolates. In total, $24 \mathrm{~B}$. cinerea isolates from Maryland, North Carolina, South Carolina, Michigan, Georgia, and Connecticut in the United States and from Canada were analyzed in this study (Table 1). Three different fungicide resistance phenotypes were 
represented, including eight isolates sensitive to seven chemical classes of fungicides (S), eight isolates resistant to at least five chemical classes of fungicides (5CCR), and eight isolates resistant to at least six chemical classes of fungicides including the phenylpyrroles (6CCR/MDR1h). The 5CCR isolates were resistant to iprodione, thiophanate-methyl, pyraclostrobin, fenhexamid, and boscalid but not to fludioxonil. Three of the eight 5CCR isolates were also resistant to cyprodinil. The $6 \mathrm{CCR} / \mathrm{MDR} 1 \mathrm{~h}$ isolates were resistant to cyprodinil, iprodione, fludioxonil, pyraclostrobin, fenhexamid, and boscalid. Four of the eight 6CCR/MDR1h isolates were also resistant to thiophanate-methyl (Table 1). Resistance to the phenylpyrrole fludioxonil was due to MDR1h, as described above. Single-spore isolation was performed as previously described (Fernández-Ortuño et al. 2012). All isolates originated from either strawberry fruit or strawberry blossoms. They were collected from commercial fields between 2011 and 2014 and stored on dried filter papers at $-20^{\circ} \mathrm{C}$ (data not shown).

Genotyping of the isolates. DNA was extracted as described previously (Chi et al. 2009). The partial $\beta$-tubulin and cytochrome $b$ $(c y t b)$ genes were amplified using the primer pair TUB-F1/TUB-R1 and Qo13ext/Qo14ext with polymerase chain reaction (PCR) conditions previously described by Banno et al. (2008) and Leroux et al. (2010), respectively. The complete two-component histidine kinase gene (bos1) was amplified with five primer pairs (BF1/BR1, BF2/BR2, BF3/BR3, BF4/BR4, and BF5/BR5) following published protocols (Ma et al. 2007). The entire 3-keto reductase gene (erg27) was amplified and sequenced with primer pair erg27Beg/erg27End (Fillinger et al. 2008). The $s d h B$ gene was amplified using the primer pair IpBcBeg/IpBcEnd2, as described previously (Leroux et al. 2010). The mrrl gene was amplified from 6CCR/MDR1h isolates with primers mrr1_atg/TF1-2_new for the upstream fragment and TF1-3_new/TF1-4 for the downstream fragment (Kretschmer et al. 2009; Leroch et al. 2013).

PCR products were purified using the ExoSAP-IT PCR purification kit (USB Corporation, Cleveland, $\mathrm{OH}$ ) following the manufacturer's instructions and Sanger sequencing was conducted at the Clemson University Genomics Institute, Clemson, SC.
Fitness components. The following fitness components were determined: (i) mycelial growth in vitro, (ii) osmotic sensitivity in vitro, (iii) oxidative sensitivity in vitro, (iv) aggressiveness and spore production in vivo, and (v) sclerotial production and viability in vitro. All experiments were conducted twice.

To investigate mycelial growth rates, mycelial plugs $(5 \mathrm{~mm}$ in diameter) were removed from the margins of 3-day-old cultures actively growing on potato dextrose agar (PDA) (Difco Laboratories, Sparks, MD) in petri dishes $(90 \mathrm{~mm})$. Plugs were placed upside down at the center of fresh PDA plates. The plates were incubated at 4, 22, and $30^{\circ} \mathrm{C}$ in the dark for 4 days. For each isolate, three replicate dishes were used. The diameter of each colony was measured after 4 days.

When microorganisms are placed into a hypertonic environment where the concentration of solute is higher outside the cell, water is lost from the cell, resulting in dehydration, shrinkage of the plasma membrane, and eventual death. To investigate the ability to withstand plasmolysis by exposure to $\mathrm{NaCl}$-amended medium, mycelial plugs were taken from the margin of 3-day-old colonies and placed upside down at the center of PDA medium amended with 2,4 , or $6 \% \mathrm{NaCl}$. For each isolate, three replicate plates were used. After 4 days of incubation at $22^{\circ} \mathrm{C}$ in the dark, colony diameters were measured.

Generation of reactive oxygen species (ROS) occurs at the hostfungus interface during $B$. cinerea infections (Prins et al. 2000; Schouten et al. 2002). ROS play a major role in fungus-plant interactions as signaling components in both partners (Heller and Tudzynski 2011). Thus, oxidative stress adaptation is essential for pathogenicity. To measure the oxidative sensitivity, mycelial growth was measured at $22^{\circ} \mathrm{C}$ on PDA amended with $100 \mu \mathrm{M}$ menadione, paraquat at $100 \mu \mathrm{g} / \mathrm{ml}$, or $10 \mathrm{mM} \mathrm{H}_{2} \mathrm{O}_{2}$ (Giesbert et al. 2012; Temme and Tudzynski 2009). Three petri dishes per set of conditions were inoculated with agar plugs containing 3-day-old mycelium $(5 \mathrm{~mm}$ in diameter). Colony diameters were measured after 4 days of incubation at $22^{\circ} \mathrm{C}$ in the dark.

Aggressiveness and spore production were determined on detached organic apple fruit ('Gala'). Apple fruit of similar size and commercial maturity were disinfected by immersion in $1 \%$

TABLE 1. Fungicide resistance phenotype, origin of isolation, and presence or absence of associated point mutations in the class III histidine kinase (bos 1), $\beta$-tubulin, cytochrome $\mathrm{b}(\mathrm{cytb})$, partial 3-keto reductase (erg27), and succinate dehydrogenase iron-sulfur protein $(s d h B)$

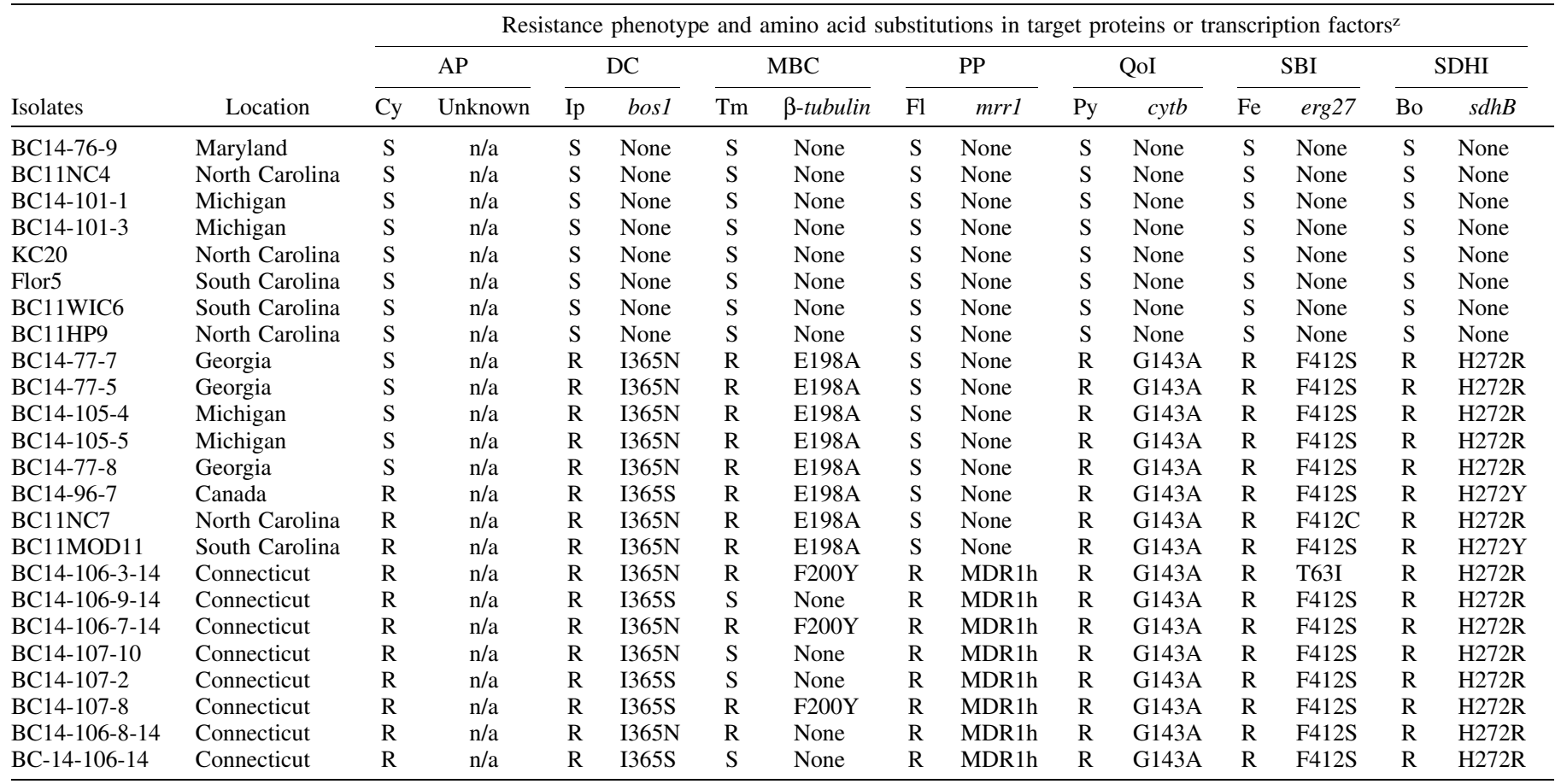

z Abbreviations: $\mathrm{AP}=$ anilino-pyrimidines, $\mathrm{DC}=$ dicarboximides, $\mathrm{MBC}=$ methyl benzimidazolecarbamates, $\mathrm{PP}=$ phenylpyrroles, $\mathrm{QoI}=$ quinone outside inhibitors, SBI = sterol biosynthesis inhibitors, SDHI = succinate dehydrogenase inhibitors, Cy = cyprodinil, Ip $=$ iprodione, Tm $=$ thiophanate-methyl, $\mathrm{Fl}=$ fludioxonil, $\mathrm{Py}=$ pyraclostrobin, $\mathrm{Fe}=$ fenhexamid, $\mathrm{Bo}=$ boscalid, $\mathrm{S}=$ sensitive, $\mathrm{R}=$ resistant, and $\mathrm{n} / \mathrm{a}=$ not applicable. 
(vol/vol) sodium hypochlorite solution for $5 \mathrm{~min}$, rinsed three times in sterile deionized water, and subsequently air dried. Spores were produced on PDA after 10 days of incubation at $22^{\circ} \mathrm{C}$ under continuous light. Spore suspensions were prepared in Gamborg Minimal Medium (3 g of Gamborg B5 basal salt mixtures, $1.36 \mathrm{~g}$ of $\mathrm{KH}_{2} \mathrm{PO}_{4}$, and $9.9 \mathrm{~g}$ of glucose per liter of medium) and adjusted to $5 \times 10^{5}$ spores $/ \mathrm{ml}$ with the aid of a hemocytometer. A $20-\mu$ d droplet of the conidial suspension was placed with three equidistant points on apple fruit. A 0.9 -mm-diameter needle was used to make a wound on the fruit to an approximate depth of $4 \mathrm{~mm}$ below the epidermis. Inoculated fruit were placed in boxes, covered with a plastic bag to keep the relative humidity approximately $100 \%$, and maintained at room temperature at approximately $20^{\circ} \mathrm{C}$. Lesion diameters were measured after 5 days. For each isolate, three replicate apple fruit were inoculated. To determine spore production, a piece of decayed tissue ( 8 by 8 by $2 \mathrm{~cm}$ ) was cut from the fruit with a sterile scalpel 10 days after inoculation and placed in a sandwich box (18 by 18 by $10 \mathrm{~cm}$ ) with two layers of moist paper towels on the bottom of the plate and open lid to maintain high relative humidity. After 3 days of incubation, conidia were rinsed off the decayed tissue with $10 \mathrm{ml}$ of sterile water by sterile cotton swabs. The suspension was transferred to $50-\mathrm{ml}$ tubes with 10 glass beads and vortexed for $1 \mathrm{~min}$. The concentration of conidia was determined using a hemacytometer. Mean conidia production of three replicates was determined for each isolate.

Sclerotia are a compact mass of hardened fungal mycelium that enable $B$. cinerea to survive environmental extremes. They are also involved in sexual reproduction. For determination of sclerotia production in vitro and assessment of sclerotia viability under different storage conditions, PDA plates inoculated with agar plugs containing actively growing mycelium were incubated in the dark at 4 and $22^{\circ} \mathrm{C}$ for 6 and 10 weeks. The number of sclerotia formed in each plate was counted visually. For each isolate, three replicates were used. Sclerotia were harvested from PDA medium after 4 weeks of incubation in the dark. They were sterilized by immersing for $1 \mathrm{~min}$ in $70 \%$ (vol/vol) ethanol, rinsed twice in sterile water, and dried with sterile filter paper (Mosbach et al. 2011). The sclerotia were stored in $1.5-\mathrm{ml}$ tubes at 4 and $22^{\circ} \mathrm{C}$. Three replicate tubes were prepared per isolate and storage temperature, with 10 sclerotia in each tube. After 1 and 3 months, viability was determined by calculating the percentage of sclerotia that had germinated after $72 \mathrm{~h}$ of incubation on PDA in the dark.

Stability of resistance to fludioxonil and other fungicides in 6CCR/MDR1h isolates. The stability of resistance to fludioxonil in five 6CCR/MDR1h isolates (BC14-106-3-14, BC14-106-9-14, BC14107-8, BC106-8-14, and BC106-6-14) was determined by culturing the isolates on untreated, organically grown apple halves (Gala). The spores generated at each of four transfers were harvested into Gamborg Minimal Medium and used to reinoculate new apple halves. Droplets $(20 \mu \mathrm{l})$ containing $5 \times 10^{5}$ conidia/ml were placed at six equidistant points on the surface of each apple half. Three inoculated apple halves were prepared for each isolate and halves were placed in an enclosed plastic container ( 18 by 18 by $10 \mathrm{~cm}$ ) and incubated at room temperature. After 7 days, lids were removed and halves were incubated for another 7 days to facilitate sporulation. Before the first and after the last transfer, the effective inhibitory dose at which $50 \%$ inhibition occurs $\left(\mathrm{EC}_{50}\right.$ in micrograms per milliliter) was determined for fludioxonil using a germ tube elongation assay. Briefly, aliquots of $100 \mu \mathrm{l}$ of conidial suspensions at $10^{5}$ spores $/ \mathrm{ml}$ were plated on petri dishes with malt extract agar (MEA) amended with fludioxonil at 0 , $0.003,0.01,0.03,0.1,0.3,1$, and $3 \mu \mathrm{g} / \mathrm{ml}$. After $16 \mathrm{~h}$ of incubation at $22^{\circ} \mathrm{C}$ in the dark, $70 \%$ ethanol was sprayed onto the surface of all plates to stop fungal growth. The germination rate and germ tube length were determined for 50 spores/plate, with three plates per treatment under an Olympus BX41 microscope, using a micrometer. The five 6CCR/ MDR1h isolates were also transferred individually onto fludioxoniltreated apple halves. Apple halves were immersed for $1 \mathrm{~min}$ in fludioxonil suspension (Scholar; Syngenta Crop Sciences, Raleigh,
$\mathrm{NC})$ at $100 \mu \mathrm{g} / \mathrm{ml}$. Inoculation and data collection were carried out as described above.

The response of $6 \mathrm{CCR} / \mathrm{MDR} 1 \mathrm{~h}$ isolates to six other fungicides at discriminatory doses was also determined before the first and after the fourth transfer, as described previously (Fernández-Ortuño et al. 2014). Briefly, Czapek-Dox agar medium with cyprodinil (Vangard WG fungicide; Syngenta Crop Protection, Raleigh, NC) at $4 \mu \mathrm{g} / \mathrm{ml}$, fenhexamid (Elevate $50 \mathrm{WDG}$; Arysta Life Science, New York) at $50 \mu \mathrm{g} / \mathrm{ml}$, iprodione (Rovral 4 Flowable; Bayer Crop Sciences, Morrisville, NC) at $10 \mu \mathrm{g} / \mathrm{ml}$, pyraclostrobin (Cabrio EG fungicide $20 \%$ W/W; BASF Corporation, Ludwigshafen, Germany) at 10 $\mu \mathrm{g} / \mathrm{ml}$, or thiophanate-methyl (Topsin M 70WP; United Phosphorus, Inc., Cheshire, UK) at $100 \mu \mathrm{g} / \mathrm{ml}$, and $1 \%$ yeast bacto acetate agar with boscalid (Endura fungicide $70 \%$ [wt/wt]; BASF Corporation) at $75 \mu \mathrm{g} / \mathrm{ml}$ were used to assess sensitivity in the form of mycelial growth to fungicides described as above.

Competition experiments. Experimental design. Five $S$ isolates (BC14-101-1, BC14-101-3, Flor5, BC11WIC6, and BC11HP9), five 5CCR isolates (BC14-77-7, BC14-77-5, BC14-96-7, BC11NC7, and BC11MOD11), and five 6CCR/MDR1h isolates (BC14-106-3-14, $\mathrm{BC} 14-106-9-14, \mathrm{BC} 14-107-8, \mathrm{BC} 106-8-14$, and $\mathrm{BC} 106-6-14)$ were used in the competition experiments. Although all isolates originated from strawberry fruit, apple fruit were chosen to avoid the more frequent contamination issues when working with strawberry. All isolates had similar growth rates and sporulation ability on apple fruit (data not shown). Each of the fungicide resistance phenotypes (S, 5CCR, and 6CCR/MDR1h) were represented by five isolates with equal spore proportions (designated phenotype mixture). Competition experiments were conducted with and without fungicide exposure. Conidial suspensions were prepared with mixtures of the S, 5CCR, and 6CCR/MDR1h isolates using different combinations and conidia ratios at $5 \times 10^{5}$ conidia $/ \mathrm{ml}$. Experiments without fungicide exposure were conducted with mixtures of 6CCR/MDR1h and S isolates, 5CCR isolates and $\mathrm{S}$ isolates, and 6CCR/MDR1h and 5CCR isolates at a ratio of 1:1. Experiments with mixtures of 6CCR/MDR1h and $\mathrm{S}$ isolates were also examined at ratios of 3:1 and 9:1. Experiments with fungicide exposure were conducted with mixtures of S, 5CCR, and 6CCR/ MDR1h at a ratio of 79:20:1, respectively.

Fungicide exposure consisted of rotating fludioxonil and pyraclostrobin starting with fludioxonil at the first transfer. Six fruit halfreplicates were used for each combination. Each phenotype was transferred separately to examine viability separately over the course of the experiment. The experiments were terminated after four transfers and repeated twice.

Artificial inoculation of apple fruit. For the competition test in the absence of fungicides, organic apple fruit (Gala) were prepared, wounded, inoculated, and incubated as described above in the "Aggressiveness and spore production" section. After 10 days of incubation at room temperature, the symptomatic fruit were longitudinally cut into halves and incubated for another 3 days in open-lid containers to induce sporulation on the cut surface. Apple halves were used for all experiments using fungicide treatments instead of the intact apple, which reduced variability between replicates. Apple halves were immersed for $1 \mathrm{~min}$ in a fludioxonil suspension (commercial grade) at $100 \mu \mathrm{g}$ a.i./ml prior to the first and third transfer and in a pyraclostrobin suspension at $100 \mu \mathrm{g}$ a.i. $/ \mathrm{ml}$ prior to the second and fourth transfer. Conidia produced on each apple half were collected by scraping the sporulating area with premoistened sterile cotton swabs and transferred into a 15-ml tube containing $10 \mathrm{ml}$ of Gamborg Minimal Medium and used for determination of phenotype frequency after each transfer.

Determination of $6 C C R / M D R 1 h$ and $5 C C R$ frequencies. To distinguish 6CCR/MDR1h conidia from 5CCR and S conidia, $100 \mu \mathrm{l}$ of spore suspension $\left(1.0 \times 10^{5}\right.$ conidia $\left./ \mathrm{ml}\right)$ was transferred to MEA in petri dishes amended with fludioxonil at $0.3 \mu \mathrm{g} / \mathrm{ml}$, the dose at which only 6CCR/MDR $1 \mathrm{~h}$ but not $\mathrm{S}$ and 5CCR isolates germinated. To distinguish 5CCR conidia from $\mathrm{S}$ conidia, spores were transferred to $1 \%$ MEA amended with pyraclostrobin at 
$10 \mu \mathrm{g} / \mathrm{ml}$ and alternative oxidase inhibitor salicylhydroxamic at $100 \mu \mathrm{g} / \mathrm{ml}$. At the dose of pyraclostrobin at $10 \mu \mathrm{g} / \mathrm{ml}$, only 5 CCR but not $\mathrm{S}$ conidia germinated. Six replicate plates were investigated for each treatment. The plates were incubated for $16 \mathrm{~h}$ in the dark. At least 100 conidia/plate were examined for germination microscopically.

Data analysis. Student's $t$ test for equality of variance was conducted to determine whether two experimental runs could be combined. If there was no significant $(P>0.05)$ difference between runs, pooled data were used for analysis of variance. Fisher's protected least significant difference test was used to assess the differences of fitness components and the stability of resistance to fludioxonil in 6CCR/MDR $1 \mathrm{~h}$ isolates at $P=0.05$. In the competition test, data from the two replicates were merged. The frequencies of observed resistant isolates were compared with the initial frequencies using the $\chi^{2}$ test. All the statistical analysis tests were performed using SPSS Software (release 13.0; SPSS Inc., Chicago).

\section{RESULTS}

Molecular basis of resistance. None of the isolates sensitive to iprodione, thiophanate-methyl, pyraclostrobin, fenhexamid, and boscalid had sequence variations in target genes. The eight 5CCR isolates revealed at least three different genotypes with mutations I365 N/S in bos1, E198A in $\beta$-tubulin, G143A in cytb, F412S/C in erg27, and $\mathrm{H} 272 \mathrm{R} / \mathrm{Y}$ in $s d h B$ (Table 1), and none of them were resistant to fludioxonil. The eight isolates resistant to fludioxonil were identified to be MDR $1 \mathrm{~h}$ due to $\Delta 497 \mathrm{~V} / \mathrm{L}$ in the $m r r l$ gene. These isolates consisted of different genotypes with mutations I365 $\mathrm{N} / \mathrm{S}$ in bos1, either no mutation or the F200Y mutation in $\beta$-tubulin, G143A in $c y t b, \mathrm{~F} 412 \mathrm{~S}$ or T63I in erg27, and H272R in $s d h B$. Because resistance to fungicides other than fludioxonil and cyprodinil (unknown) was based on point mutations in target genes, resistance was at the same qualitative level for both isolate groups.

Fitness components. Mycelial growth. Mycelial growth rate between $\mathrm{S}$ isolates and 6CCR/MDR1h isolates was not different at all temperatures examined, with one exception. The 6CCR/MDR1h isolates grew significantly more slowly $(P<0.05)$ compared with the $\mathrm{S}$ isolates and 5CCR isolates at $4^{\circ} \mathrm{C}$ but no significant differences in mycelial growth rate were observed among the phenotypes at 22 and $30^{\circ} \mathrm{C}$ (Table 2).

Sensitivity to osmotic and oxidative stress. The 5CCR and 6CCR/ MDR1h isolates were significantly more susceptible $(P<0.05)$ to salt stress compared with the $\mathrm{S}$ isolates regardless of the $\mathrm{NaCl}$ dose, except for the 6CCR/MDR1h isolates at $6 \% \mathrm{NaCl}$ (Table 2). No significant difference in the ability to cope with oxidative stress was observed among the S, 5CCR, and 6CCR/MDR1h isolates (Table 2).

Determination of lesion size, conidia and sclerotia production, and sclerotia viability. All isolates used in the study were pathogenic on wounded apple. Aggressiveness was estimated by lesion size and sporulation ability. S, 5CCR, and 6CCR/MDR1h isolates did not differ significantly in the ability to cause decay and sporulation on apple fruit (Table 3). Likewise, no significant differences were observed among S, 5CCR, and 6CCR/MDR1h isolates in their ability to produce sclerotia $(P>0.05)$ and the ability of sclerotia to survive for up to 3 months at different temperatures $(P<0.05)$ (Table 4$)$. However, significant decrease of sclerotia production was found for 6CCR/MDR1h isolates when incubation temperature changed from 22 to $4^{\circ} \mathrm{C}$. For the 5CCR and $\mathrm{S}$ isolates, the change of temperature didn't have a significant effect on the production of sclerotia (Table 5).

Stability of resistance to fludioxonil and other fungicides. After four transfers on both untreated and fludioxonil-treated apple halves, all 6CCR/MDR1h isolates were still able to germinate with fludioxonil at $1 \mu \mathrm{g} / \mathrm{ml}$. The $\mathrm{EC}_{50}$ values obtained before the first (T0) and after the last (T4) transfer for 6CCR/MDR1h isolates grown on nonfungicide-treated fruit fluctuated slightly; however, the mean values were not statistically different $(P=0.05)$ (Table 6$)$. Likewise, the mean resistance factors for T0 and T4 were not significantly different. The mean $\mathrm{EC}_{50}$ values and resistance factor values of $6 \mathrm{CCR} / \mathrm{MDR} 1 \mathrm{~h}$ isolates between T0 and TF4 were also not significantly different $(P<0.05)$ (Table 6). All 6CCR/MDR1h isolates maintained their ability to grow on medium with discriminatory doses of cyprodinil, iprodione, fludioxonil, pyraclostrobin, fenhexamid, and boscalid fungicides, indicating stability of resistance to these fungicides as well (data not shown).

Competition test. Over the course of the competition experiment, the viability of each phenotype mixture was monitored separately throughout the four transfers. At the fourth transfer, all isolates produced similar-sized lesions and produced similar amount of spores compared with the first transfer (Table 7), indicating no loss in aggressiveness.

In competition with $\mathrm{S}$ isolates, the $5 \mathrm{CCR}$ isolates steadily were outcompeted over the four transfers. By the fourth cycle, the proportion of 5CCR isolates had dropped to less than $8 \%$ (Fig. 1A).

The 6CCR/MDR1h isolates failed to compete effectively with $\mathrm{S}$ or 5CCR isolates (Fig. 1B and C). A sharp decline $(P<0.05)$ of the 6CCR/MDR1h isolate frequency was observed even after the first transfer. At the end of the fourth cycle in mixtures with $\mathrm{S}$ and $5 \mathrm{CCR}$

TABLE 3. Lesion size and sporulation of Botrytis cinerea isolates with different fungicide resistance phenotypes on detached apple fruit ${ }^{\mathrm{w}}$

\begin{tabular}{llc}
\hline Phenotype $^{\mathrm{x}}$ & Lesion size $^{\mathrm{y}}$ & Sporulation $^{\mathrm{z}}$ \\
\hline $\mathrm{S}$ & $20.2 \pm 5.2 \mathrm{a}$ & $5.8 \pm 3.0 \mathrm{a}$ \\
5CCR & $23.0 \pm 5.8 \mathrm{a}$ & $7.0 \pm 3.0 \mathrm{a}$ \\
6CCR/MDR1h & $22.8 \pm 4.8 \mathrm{a}$ & $7.7 \pm 2.3 \mathrm{a}$
\end{tabular}

w Values are means \pm standard error from the average of eight isolates for each phenotype group. Shown are combined data from two biological replicates. Numbers in each column followed by the same letter are not significantly different according to Fisher's protected least significant difference test at $P=0.05$.

${ }^{x} \mathrm{~S}=$ sensitive to all the fungicides tested; $5 \mathrm{CCR}=$ resistant to at least five fungicides of different chemical classes, with the exception of fludioxonil; and $6 \mathrm{CCR} / \mathrm{MDR} 1 \mathrm{~h}=$ resistant to fludioxonil and other fungicides of different chemical classes.

y Mycelial growth was measured after 5 days of incubation.

$\mathrm{z}$ Number of spores $\left(\times 10^{3}\right)$ per square centimeter of lesion.

TABLE 2. Radial mycelial growth, osmotic sensitivity, and oxidative sensitivity of Botrytis cinerea isolates with different fungicide resistance phenotypes

\begin{tabular}{|c|c|c|c|c|c|c|c|c|c|}
\hline \multirow[b]{2}{*}{ Phenotype ${ }^{z}$} & \multicolumn{3}{|c|}{ Mycelial growth ${ }^{w}$} & \multicolumn{3}{|c|}{ Osmotic sensitivity $^{\mathrm{x}}$} & \multicolumn{3}{|c|}{ Oxidative sensitivity } \\
\hline & $4^{\circ} \mathrm{C}$ & $22^{\circ} \mathrm{C}$ & $30^{\circ} \mathrm{C}$ & $6 \%$ & $4 \%$ & $2 \%$ & Menadione & Paraquat & $\mathrm{H}_{2} \mathrm{O}_{2}$ \\
\hline $\mathrm{S}$ & $6.2 \pm 0.5 \mathrm{a}$ & $24.5 \pm 1.4 \mathrm{a}$ & $16.5 \pm 1.4 \mathrm{a}$ & $9.2 \pm 1.8 \mathrm{a}$ & $19.0 \pm 0.7 \mathrm{a}$ & $25.0 \pm 1.1 \mathrm{a}$ & $15.9 \pm 2.5 \mathrm{a}$ & $19.1 \pm 0.9 \mathrm{a}$ & $14.5 \pm 0.4 \mathrm{a}$ \\
\hline $5 \mathrm{CCR}$ & $5.6 \pm 0.4 \mathrm{a}$ & $24.4 \pm 1.2 \mathrm{a}$ & $14.5 \pm 2.4 \mathrm{a}$ & $7.7 \pm 1.2 \mathrm{~b}$ & $16.5 \pm 1.9 \mathrm{~b}$ & $20.3 \pm 6.9 b$ & $15.1 \pm 1.8 \mathrm{a}$ & $17.1 \pm 1.6 \mathrm{a}$ & $14.6 \pm 0.5 \mathrm{a}$ \\
\hline 6CCR/MDR1h & $5.0 \pm 0.7 \mathrm{~b}$ & $23.1 \pm 2.3 \mathrm{a}$ & $12.3 \pm 4.6 \mathrm{a}$ & $7.8 \pm 1.5 \mathrm{ab}$ & $16.5 \pm 1.4 \mathrm{~b}$ & $22.7 \pm 2.0 \mathrm{~b}$ & $16.6 \pm 3.8 \mathrm{a}$ & $16.9 \pm 1.2 \mathrm{a}$ & $15.7 \pm 2.7 \mathrm{a}$ \\
\hline
\end{tabular}

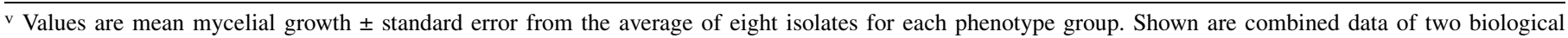
replicates. Numbers in each column followed by the same letter are not significantly different according to Fisher's protected least significant difference test at $P=0.05$.

${ }^{w}$ Mycelial growth was measured after 4 days of incubation on potato dextrose agar.

${ }^{x}$ Mean colony diameter in the presence of $\mathrm{NaCl}$ at $22^{\circ} \mathrm{C}$.

y Mean colony diameter in the presence of menadione $(100 \mu \mathrm{M})$, paraquat $(100 \mu \mathrm{g} / \mathrm{ml})$, and $10 \mathrm{mM} \mathrm{H}_{2} \mathrm{O}_{2}$ at $22^{\circ} \mathrm{C}$.

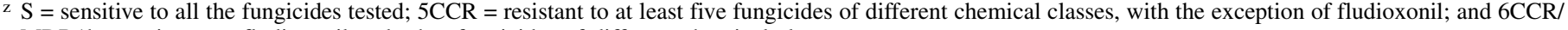
$\mathrm{MDR} 1 \mathrm{~h}=$ resistant to fludioxonil and other fungicides of different chemical classes. 
isolates, the 6CCR/MDR1h isolates had almost disappeared and were found at frequencies of 0.20 and $1.05 \%$, respectively (Fig. 1B and $\mathrm{C}$ ). When the 6CCR/MDR $1 \mathrm{~h}$ isolates and $\mathrm{S}$ isolates were mixed at ratios of 3:1 and 9:1, the frequency of $6 \mathrm{CCR} / \mathrm{MDR} 1 \mathrm{~h}$ isolates decreased gradually to nearly $0 \%$ in both cases, despite the initial disadvantage in spores being outnumbered. After only three transfers, the spores of 6CCR/MDR1h isolates were found at frequencies of 1.25 and $4.49 \%$, respectively (Fig. 2).

As expected, when the competition assay was conducted on apple halves treated with label rates of fludioxonil and pyraclostrobin fungicides, the frequency of 6CCR/MDR1h isolates increased sharply after the first transfer from 1 to $97 \%$ (Fig. 3).

\section{DISCUSSION}

B. cinerea is a pathogen at high risk for fungicide resistance development due to its high genetic variability (Leroux et al. 2002), abundance of sporulation, short generation time (Petsikos-Panayotarou et al. 2003), and wide host range (Yourman et al. 2001). Resistance to three or more fungicide classes is commonly found in $B$. cinerea from conventional strawberry fields (Bardas et al. 2010; Fernández-Ortuño et al. 2015; Leroch et al. 2013) and isolates with resistance to five and more classes of fungicides have emerged in the United States. Management of these isolates will be challenging because isolates resistant to multiple classes of fungicides may not be controlled when alternating or mixing compounds belonging to these different classes of fungicides. More emphasis must be given to the reduction of inoculum to reduce selection pressure. One way to reduce inoculum of multifungicide-resistant isolates would be to eliminate selection pressure in hopes that reduced fitness and competitiveness will favor wild-type strains and reduce the proportion of multifungicide-resistant isolates in the population.

In this study, phenotypes S, 5CCR, and 6CCR/MDR1h were examined. The isolates representing each phenotype were purposely chosen to originate from different locations so that they would not be genetically identical to avoid genotypic bias. The $\mathrm{S}$ isolates came from Maryland, North Carolina, Michigan, and South Carolina and were collected in two different years. The 5CCR isolates were collected from Georgia, Michigan, North Carolina, South Carolina, and Canada and represented at least three different genotypes based on target gene variations. Although all 6CCR/ MDR1h isolates were from Connecticut, they had unique compositions of mutations in target genes and at least five different genotypes based on target gene modifications were represented. For

TABLE 4. Sclerotia production and viability (\%) of Botrytis cinerea isolates with different fungicide resistance phenotypes

\begin{tabular}{|c|c|c|c|c|c|c|c|c|}
\hline \multirow[b]{3}{*}{ Phenotype $^{z}$} & \multicolumn{4}{|c|}{ Sclerotia production $^{\mathrm{x}}$} & \multicolumn{4}{|c|}{ Sclerotia viability $(\%)^{\mathrm{y}}$} \\
\hline & \multicolumn{2}{|c|}{$4^{\circ} \mathrm{C}$} & \multicolumn{2}{|c|}{$22^{\circ} \mathrm{C}$} & \multicolumn{2}{|c|}{$4^{\circ} \mathrm{C}$} & \multicolumn{2}{|c|}{$22^{\circ} \mathrm{C}$} \\
\hline & 6 weeks & 10 weeks & 6 weeks & 10 weeks & 1 month & 3 month & 1 month & 3 month \\
\hline S & $38.0 \pm 50.5 \mathrm{a}$ & $41.2 \pm 55.1 \mathrm{a}$ & $60.7 \pm 18.8 \mathrm{a}$ & $62.1 \pm 18.8 \mathrm{a}$ & 90.9 a & $94.7 \mathrm{a}$ & $56.0 \mathrm{a}$ & $65.3 \mathrm{a}$ \\
\hline $5 \mathrm{CCR}$ & $53.0 \pm 41.0 \mathrm{a}$ & $54.2 \pm 41.8 \mathrm{a}$ & $47.9 \pm 57.6 \mathrm{a}$ & $56.9 \pm 56.8 \mathrm{a}$ & $100 \mathrm{a}$ & $100 \mathrm{a}$ & $80.0 \mathrm{a}$ & $97.5 \mathrm{a}$ \\
\hline 6CCR/MDR1h & $23.4 \pm 27.3 \mathrm{a}$ & $37.3 \pm 43.0 \mathrm{a}$ & $71.8 \pm 44.1 \mathrm{a}$ & $76.1 \pm 48.5 \mathrm{a}$ & $92.0 \mathrm{a}$ & $100 \mathrm{a}$ & $95.5 \mathrm{a}$ & $87.5 \mathrm{a}$ \\
\hline
\end{tabular}

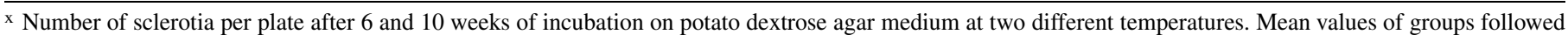
by the same letter are not significantly different according to Fisher's protected least significant difference test at $P=0.05$.

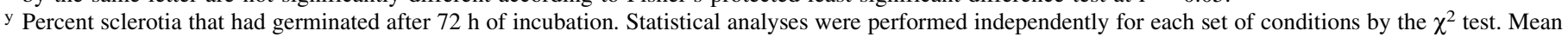
values of groups followed by the same letter are not significantly different at $P=0.05$.

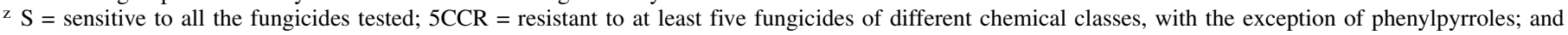
$6 \mathrm{CCR} / \mathrm{MDR} 1 \mathrm{~h}=$ resistant to fludioxonil and other fungicides of different chemical classes.

TABLE 5. Influence of temperature (Temp) on sclerotia production of Botrytis cinerea isolates with different fungicide resistance phenotypes

\begin{tabular}{|c|c|c|c|c|c|c|}
\hline \multirow[b]{3}{*}{ Temp } & \multicolumn{6}{|c|}{ Sclerotia production ${ }^{z}$} \\
\hline & \multicolumn{3}{|c|}{6 weeks } & \multicolumn{3}{|c|}{10 weeks } \\
\hline & $\mathrm{S}$ & $5 \mathrm{CCR}$ & 6CCR/MDR1h & $\mathrm{S}$ & $5 \mathrm{CCR}$ & 6CCR/MDR $1 \mathrm{~h}$ \\
\hline $22^{\circ} \mathrm{C}$ & $60.7 \pm 18.8 \mathrm{a}$ & $47.9 \pm 57.6 \mathrm{a}$ & $71.8 \pm 44.1 \mathrm{a}$ & $62.1 \pm 18.8 \mathrm{a}$ & $56.9 \pm 56.8 \mathrm{a}$ & $76.1 \pm 48.5 \mathrm{a}$ \\
\hline $4^{\circ} \mathrm{C}$ & $38.0 \pm 50.5 \mathrm{a}$ & $53.0 \pm 41.0 \mathrm{a}$ & $23.4 \pm 27.3 b$ & $41.2 \pm 55.1 \mathrm{a}$ & $54.2 \pm 41.8 \mathrm{a}$ & $37.3 \pm 43.0 \mathrm{~b}$ \\
\hline
\end{tabular}

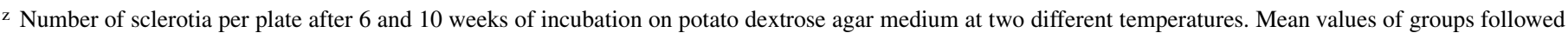
by the same letter are not significantly different according to Fisher's protected least significant difference test at $P=0.05$. $\mathrm{S}=$ sensitive to all the fungicides tested; $5 \mathrm{CCR}=$ resistant to at least five fungicides of different chemical classes, with the exception of phenylpyrroles; and $6 \mathrm{CCR} / \mathrm{MDR} 1 \mathrm{~h}=$ resistant to fludioxonil and other fungicides of different chemical classes.

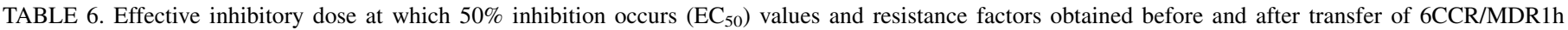
isolates on apple with and without fludioxonil treatment ${ }^{\mathrm{x}}$

\begin{tabular}{|c|c|c|c|c|c|c|}
\hline \multirow[b]{2}{*}{ Isolates } & \multicolumn{3}{|c|}{$\mathrm{EC}_{50}(\mu \mathrm{g} / \mathrm{ml})$} & \multicolumn{3}{|c|}{ Resistance factor ${ }^{\mathrm{y}}$} \\
\hline & T0 & $\mathrm{T} 4$ & TF4 & T0 & $\mathrm{T} 4$ & TF4 \\
\hline BC106-6-14 & 0.1 & 0.1 & 0.2 & 9.9 & 6.9 & 14.8 \\
\hline BC106-8-14 & 0.3 & 0.1 & 0.3 & 22.0 & 9.8 & 22.9 \\
\hline BC14-107-8 & 0.2 & 0.2 & 0.3 & 14.5 & 13.7 & 29.3 \\
\hline BC14-106-9-14 & 0.1 & 0.2 & 0.4 & 12.4 & 16.8 & 31.7 \\
\hline BC14-106-3-14 & 0.2 & 0.1 & 0.1 & 13.2 & 7.0 & 5.0 \\
\hline Mean $^{\mathrm{z}}$ & $0.2 \pm 0.1 \mathrm{a}$ & $0.1 \pm 0.1 \mathrm{a}$ & $0.2 \pm 0.1 \mathrm{a}$ & $14.4 \pm 4.6 \mathrm{a}$ & $10.8 \pm 4.4 \mathrm{a}$ & $20.7 \pm 11.0 \mathrm{a}$ \\
\hline
\end{tabular}

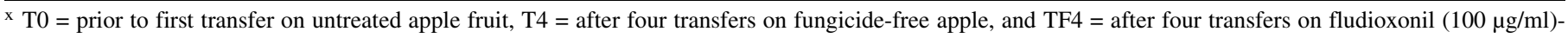
treated apple.

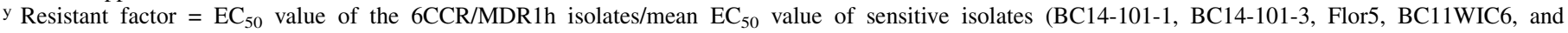
BC11HP9).

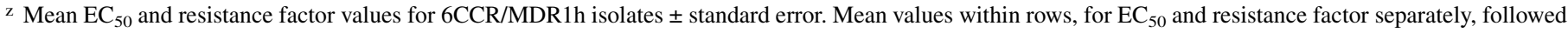
by the same letter are not significantly $(P=0.05)$ different according to Fisher's protected least significant difference test. 
example, isolate BC14-106-3-14 had mutations I365N, F200Y, G143A, T63I, and H272Y in bos 1, $\beta$-tubulin, cytb, erg27, and $s d h B$, respectively, whereas isolate BC14-106-9-14 had I365S, no mutation, G143A, F412S, and H272R, respectively. This choice of isolates representing a phenotype avoided the risk of using clones as isolate replicates but the potential high diversity within a phenotype may make direct comparisons challenging. We tried to keep the variability at a minimum, however, by selecting nearly identical numbers of group $\mathrm{S}$ isolates in each phenotype group. S and 5CCR isolates each consisted of seven group $\mathrm{S}$ isolates (out of eight each), and all 6CCR/MDR1h isolates were group S isolates based on $\mathrm{mrrl}$ gene sequence alignments (Leroch et al. 2013).

When compared with the $S$ isolates, hypersensitivity to osmotic stress was the only fitness penalty found in the 5CCR isolates. Increased sensitivity to salt stress was also reported in lab mutants or field isolates with resistance to iprodione in Botrytis spp. (Yan et al. 2010), Neurospora crassa (Fujimura et al. 2003), Rhizoctonia cerealis (Hamada et al. 2011), and Alternaria spp. (Lim et al. 2003). Hypersensitivity to salt stress in those resistant isolates may have been related to altered cell wall composition (Beever 1983; Ma et al. 2001). Thus, the 5CCR isolates may not successfully compete in nature with $\mathrm{S}$ isolates. This hypothesis was supported by our competition assays. Mixtures of $\mathrm{S}$ and 5CCR isolates resulted in a predominance of the $\mathrm{S}$ isolates over time. A similar competitive dominance of $\mathrm{S}$ isolates compared with isolates resistant to SDHI fungicides was observed in competition experiments conducted on apple (Veloukas et al. 2014).

Resistance of 5CCR isolates was solely based on point mutations in target genes. Which mutation or mutation combination may have been responsible for the observed fitness cost was not determined in this study. In previous studies, isolates possessing only cytb G143A substitution did not show fitness costs (Veloukas et al. 2014) but SDHI-resistant isolates with $\mathrm{H} 272 \mathrm{Y} / \mathrm{R} / \mathrm{L}, \mathrm{N} 230 \mathrm{I}$, or P225F $s d h B$ substitutions showed reduced fitness compared with $\mathrm{S}$ isolates (Veloukas et al. 2014). Similarly, laboratory fenhexamid-resistant mutants possessing erg 27 F412S/I/V mutations grew more slowly than the wild-type strain and displayed variations in sclerotia and conidia production (Billard et al. 2012). Other fenhexamid-resistant field isolates and UV-irradiation and chemical mutagenesis mutants with undetermined resistance mechanisms also produced fewer conidia and sclerotia (Billard et al. 2012; De Guido et al. 2007; Saito et al. 2014; Ziogas et al. 2003). Several studies showed that fludioxonil and anilinopyrimidine resistance was associated with fitness costs, specifically an increase of osmotic sensitivity (Fujimura et al. 2003; Li and Xiao 2008; Li et al. 2014b; Malandrakis et al. 2013; Markoglou et al. 2008; Zhao et al. 2010). In our study, both 5CCR and 6CCR/MDR1h isolates were more susceptible to salt and osmotic stress, which may have been a consequence of the mutations I365 N/S found in bos 1 of all isolates representing both phenotypes. This is consistent with earlier studies, where site-directed mutagenesis of the bos1 gene was applied to validate mutations including I365S, and mutants experienced reduced fitness (Fillinger et al. 2012). This increased sensitivity to osmotic stress may be due to a linkage of genes conferring iprodione and fludioxonil resistance involved in the

TABLE 7. Sporulation of Botrytis cinerea isolates with different fungicide resistance phenotypes on apple fruit over four consecutive transfers

\begin{tabular}{lcccc}
\hline Phenotype $^{2}$ & First transfer & Second transfer & Third transfer & Fourth transfer \\
\hline S & $6.3 \pm 2.0 \mathrm{a}$ & $5.4 \pm 1.4 \mathrm{a}$ & $7.2 \pm 2.8 \mathrm{a}$ & $6.6 \pm 1.2 \mathrm{a}$ \\
5CCR & $6.9 \pm 1.3 \mathrm{a}$ & $7.3 \pm 2.4 \mathrm{a}$ & $6.8 \pm 2.6 \mathrm{a}$ & $6.3 \pm 1.8 \mathrm{a}$ \\
6CCR/ & $7.2 \pm 3.3 \mathrm{a}$ & $6.8 \pm 2.5 \mathrm{a}$ & $7.5 \pm 2.5 \mathrm{a}$ & $6.5 \pm 1.1 \mathrm{a}$ \\
$\quad$ & & & \\
\hline
\end{tabular}

$\overline{\mathrm{z}}$ Number of spores $\left(\times 10^{3}\right)$ per square centimeter of lesion produced on apple fruit. $\mathrm{S}=$ sensitive to all the fungicides tested; $5 \mathrm{CCR}=$ resistant to at least five fungicides of different chemical classes, with the exception of fludioxonil; and $6 \mathrm{CCR} / \mathrm{MDR} 1 \mathrm{~h}=$ resistant to fludioxonil and other fungicides of different chemical classes. osmoregulation pathway if resistance is based on target gene mutations (Fujimura et al. 2003; Yan et al. 2010). Hypersensitivity to osmotic stress has been reported for MDR1h isolates but these isolates also possessed the I365N/S mutation (Fernández-Ortuño et al. 2015). Our study shows no direct link between the MDR1h phenotype and osmotic stress.

The MDR1h phenotype is based on enhanced activity of ATPdependent efflux transporters. Increased energy demand for active fungicide efflux may impair fitness (Buchenauer 1987). Our study shows that the 6CCR/MDR1h isolates but not 5CCR isolates had lower mycelial growth rates at $4^{\circ} \mathrm{C}$ (Table 2). Thus, it is possible that these isolates are outcompeted during cooler field days such as in the late autumn, winter, and early spring, when $B$. cinerea remains on decayed foliage and fruit and develops into sclerotia (Billard et al. 2012). Sclerotia production of $6 \mathrm{CCR} / \mathrm{MDR} 1 \mathrm{~h}$ isolates was drastically lower at $4^{\circ} \mathrm{C}$ (Table 5) compared with $22^{\circ} \mathrm{C}$, which further supports a potential weakness in overwintering ability of MDR1h isolates compared with S and 5CCR isolates. Our study is in contrast to a previous study (Fernández-Ortuño et al. 2015) showing significantly more sclerotia produced for MDR1h isolates
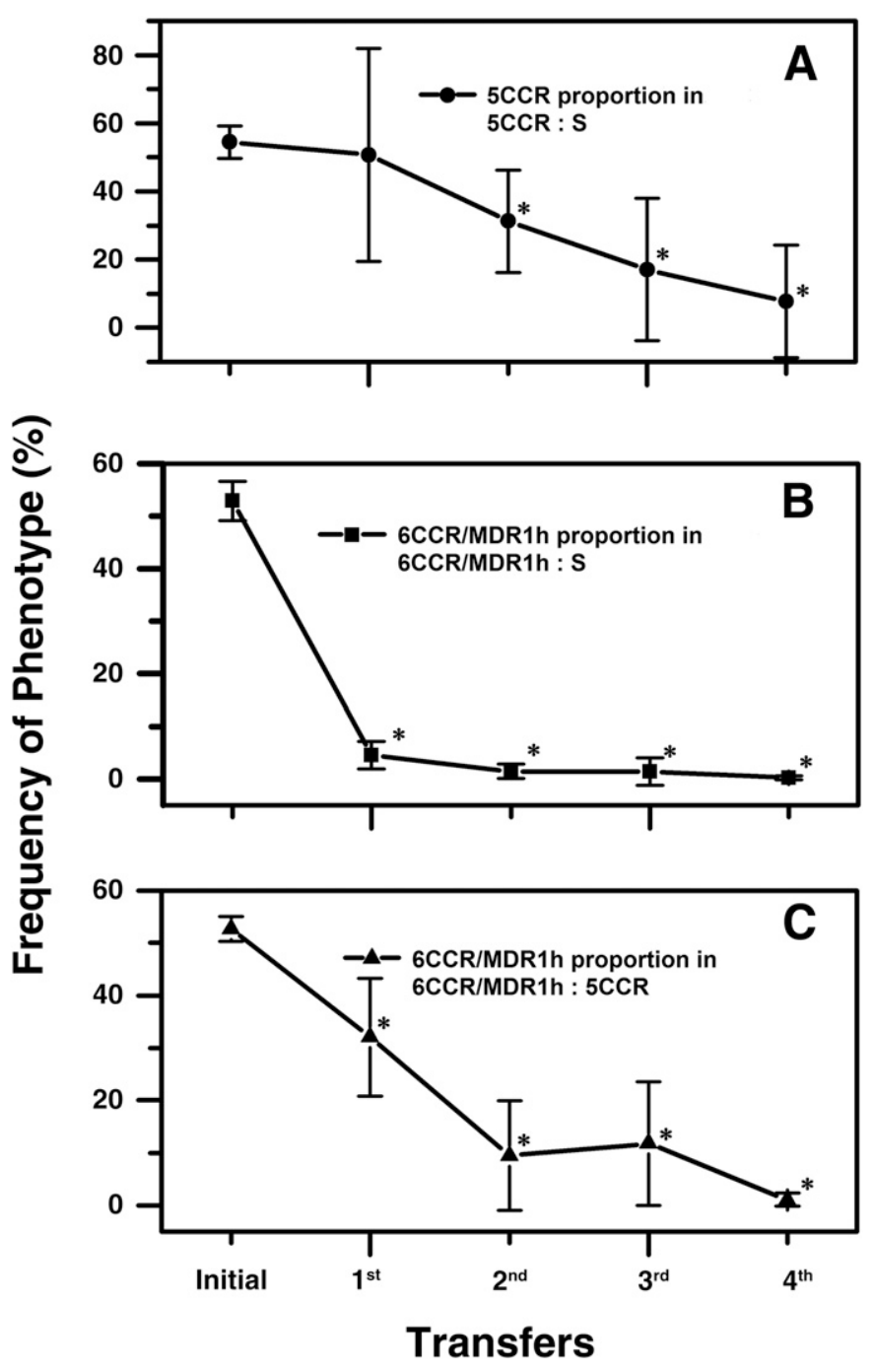

Fig. 1. Competition at 1:1 spore ratio between $\mathbf{A}, 5 \mathrm{CCR}$ and $\mathrm{S}$ isolates; $\mathbf{B}, 6 \mathrm{CCR} / \mathrm{MDR} 1 \mathrm{~h}$ and $\mathrm{S}$ isolates; $\mathbf{C}, 6 \mathrm{CCR} / \mathrm{MDR} 1 \mathrm{~h}$ and $5 \mathrm{CCR}$ isolates. $\mathrm{S}=$ sensitive to cyprodinil, iprodione, thiophanate-methyl, fludioxonil, pyraclostrobin, fenhexamid, and boscalid; $5 \mathrm{CCR}=$ resistant to at least five fungicides of different chemical classes, with the exception of fludioxonil; $6 \mathrm{CCR} / \mathrm{MDR} 1 \mathrm{~h}=$ resistant to fludioxonil and other fungicides of different chemical classes; an asterisk (*) indicates significant differences compared with the initial value according to the $\chi^{2}$ test at $P=0.05$. 
compared with $\mathrm{S}$ isolates at $11^{\circ} \mathrm{C}$ on minimal medium (MM) and intermediate medium (IM). The difference of the two studies may be explained by the limited number of isolates (three for each phenotype) used in the previous study.

Fludioxonil resistance in $B$. cinerea was stable under the experimental conditions in our study. The 6CCR/MDR1h isolates still germinated with fludioxonil at $1 \mu \mathrm{g} / \mathrm{ml}$, which is characteristic for MDR1h but not MDR1 isolates (Fernández-Ortuño et al. 2015), and isolates retained resistance after transfers on treated and untreated apple halves. The $\mathrm{EC}_{50}$ values for fludioxonil of $6 \mathrm{CCR} /$ MDR1h isolates in our study ranged from 0.11 to $0.25 \mu \mathrm{g} / \mathrm{ml}$ at T0, which were lower than the values ( 1.7 to $3.1 \mu \mathrm{g} / \mathrm{ml}$ ) reported previously (Fernández-Ortuño et al. 2015). The authors used different methods for $\mathrm{EC}_{50}$ determination, which may explain the differences. In our study, germ tube elongation was used, instead of microtiter tests which reflect inhibition of early mycelial growth rather than inhibition of germ tube elongation. Still, the ranges of resistance factors of $\mathrm{S}$ and 6CCR/MDR1h isolates were consistent with what was reported in other studies (Fernández-Ortuño et al. 2015; Hahn et al. 2014).

The detached apple assays in this study showed that $\mathrm{S}$ isolates not only were more competitive in 1:1 mixture with $6 \mathrm{CCR} / \mathrm{MDR} 1 \mathrm{~h}$ isolates but they also outcompeted 6CCR/MDR1h isolates when initially outnumbered by 9:1 in the absence of fungicide selection. We also showed a competitive advantage of 5CCR isolates when mixed with 6CCR/MDR1h isolates, which indicated yet another level of competitive disadvantage of 6CCR/MDR1h isolates. Whether the isolates originally obtained from strawberry would behave differently on the original host compared with apple was not investigated in this study. Competitive disadvantages were also observed in isolates of Saccharomyces cerevisiae exhibiting overexpression of ABC transporters (Anderson et al. 2003). The slight differences in fitness data between 5CCR, 6CCR/ MDR1h, and $\mathrm{S}$ isolates may not be enough to explain the dramatic competitive disadvantage observed in this study. However, it is possible that, during the stepwise accumulation of resistance (Li et al. 2014a), mutations elsewhere in the genome were obtained that compromised competitiveness but the effects were not identified in our fitness assays. Also, the ATP-dependent increased activity of $a \operatorname{tr} B$ and the associated increased energy requirement

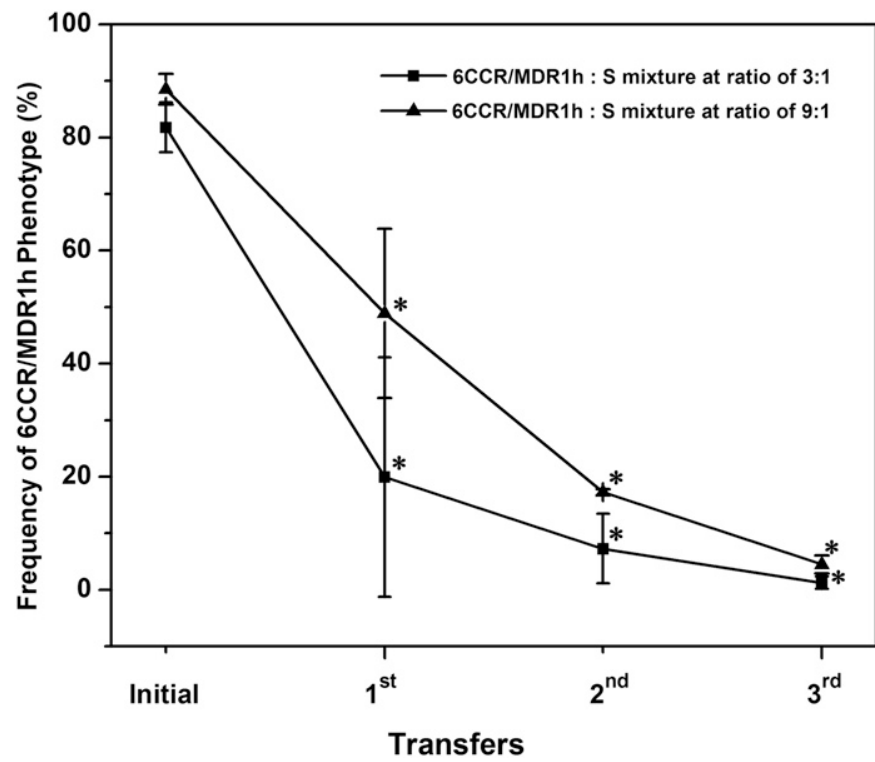

Fig. 2. Competition in vivo between $6 \mathrm{CCR} / \mathrm{MDR} 1 \mathrm{~h}$ and sensitive $(\mathrm{S})$ isolates with initial spore ratios of $3: 1$ and 9:1. Vertical lines indicate the standard error of the mean and an asterisk (*) indicates significant differences compared with the initial value according to the $\chi^{2}$ test at $P=0.05$. may have contributed to the observed fitness penalties and resulting competitive disadvantage of 6CCR/MDR1h isolates over 5CCR isolates. Whether MDR1 isolates reveal penalties similar to 6CCR/ MDR1h isolates is not known and was not examined in this study but it is reasonable to speculate that MDR1 isolates also carry a fitness cost due to almost identical mechanisms of resistance to fludioxonil due to $a t r B$ overexpression.

In contrast, when the competition test was conducted in the presence of fungicides, a rapid increase of 6CCR/MDR1h isolates was observed. In order to better simulate observations in the field that suggest that the MDR1h phenotype is still at low (equal or less than $10 \%$ ) frequencies (Fernández-Ortuño et al. 2014), we reduced the portion of MDR1h in our inoculum substantially. Also, we used fungicide rotations (fludioxonil and pyraclostrobin rotations in our transfers) to avoid one-sided selection. A rapid increase of 6CCR/MDR1h isolates was observed from $1 \%$ before the initial transfer to $97 \%$ after the first transfer. The ratio of 6CCR/MDR1h isolates remained high in subsequent transfers. Fungicide treatments reduced 5CCR and S isolates to less than 3\% in subsequent transfers. They may have been completely eradicated but that was not investigated in this study to this detail. This suggests that applications of fludioxonil in the field will select for 6CCR/MDR1h isolates and lead to changes in ratios of genotypes among the resistant population. Most growers on the U.S. east coast have been using fludioxonil regularly in rotation with other fungicides over the last 3 years but the occurrence of isolates resistant to fludioxonil has been at a steady $10 \%$ or less based on extensive resistance monitoring (data not shown). This lack of increasing frequency of fludioxonil resistance is likely a function of successful chemical rotations as well as the here-described penalty in fitness and competitive ability.

The observed fitness and competitive penalty of 5CCR and especially 6CCR/MDR1h isolates has important implications for disease management, in that this phenomenon may be exploited to reduce their proportion in the population. A simple reduction of the number of applications per season or the use of nonselective fungicides such as biologicals and multisite fungicides such as captan

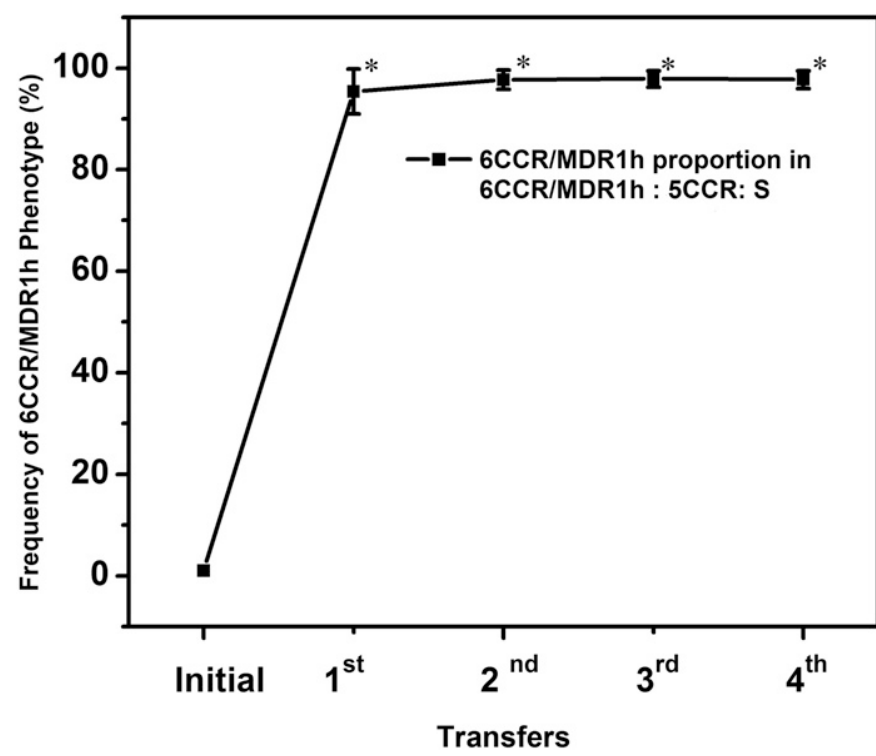

Fig. 3. Competition in vivo among $6 \mathrm{CCR} / \mathrm{MDR} 1 \mathrm{~h}, 5 \mathrm{CCR}$, and $\mathrm{S}$ isolates coinoculated on fludioxonil-treated apple fruit with initial spore ratios of 1:20:79, respectively. $\mathrm{S}=$ sensitive to fungicides; $5 \mathrm{CCR}=$ resistant to at least five fungicides of different chemical classes but not to fludioxonil; and 6CCR/ MDR1h = resistant to fludioxonil and at least five other fungicides of different chemical classes. Vertical lines indicate the standard error of the mean and an asterisk $(*)$ indicates significant differences compared with the initial value according to the $\chi^{2}$ test at $P=0.05$. 
and thiram (Legard et al. 2001; Wilcox and Seem 1994) may help reduce the proportion of MDR $1 \mathrm{~h}$ isolates in the pathogen population. Both captan and thiram are effective against MDR1 isolates based on $\mathrm{EC}_{50}$ values of approximately $1 \mu \mathrm{g} / \mathrm{ml}$ (Leroux and Walker 2013). Investigations not part of this study confirmed no loss in efficacy of captan and thiram against $6 \mathrm{CCR} / \mathrm{MDR} 1 \mathrm{~h}$ isolates for captan $\left(\mathrm{EC}_{50}\right.$ value $0.06 \mu \mathrm{g} / \mathrm{ml}$ ) and thiram $\left(\mathrm{EC}_{50}\right.$ value $0.02 \mu \mathrm{g} / \mathrm{ml}$ ) (data not shown). Efforts to implement weather-based decision support systems to reduce the number of applications per season are already made in the southeastern states (MacKenzie et al. 2012; Pavan et al. 2011).

\section{ACKNOWLEDGMENTS}

Technical contribution number 6384 of the Clemson University Experiment Station. This material is based upon work supported by the United States Department of Agriculture National Institute of Food and Agriculture (NIFA) under project number SC-1700501 and NIFA Special Crops Research Initiative grant number 2014-51181-22377. We thank P. K. Bryson for technical support.

\section{LITERATURE CITED}

Amiri, A., Heath, S., and Peres, N. 2012. Multiple fungicide resistance in Botrytis cinerea isolates from strawberry fields in Florida. Pages 4-5 in: Am. Phytopathol. Soc. Annu. Meet. St. Paul, MN.

Amiri, A., Heath, S., and Peres, N. 2013. Phenotypic characterization of multifungicide resistance in Botrytis cinerea isolates from strawberry fields in Florida. Plant Dis. 97:393-401.

Anderson, J. B., Sirjusingh, C., Parsons, A. B., Boone, C., Wickens, C., Cowen, L. E., and Kohn, L. M. 2003. Mode of selection and experimental evolution of antifungal drug resistance in Saccharomyces cerevisiae. Genetics 163:1287-1298.

Banno, S., Fukumori, F., Ichiishi, A., Okada, K., Uekusa, H., Kimura, M., and Fujimura, M. 2008. Genotyping of benzimidazole-resistant and dicarboximide-resistant mutations in Botrytis cinerea using real-time polymerase chain reaction assays. Phytopathology 98:397-404.

Bardas, G. A., Veloukas, T., Koutita, O., and Karaoglanidis, G. S. 2010. Multiple resistance of Botrytis cinerea from kiwifruit to SDHIs, QoIs and fungicides of other chemical groups. Pest Manage. Sci. 66:967-973.

Beever, R. 1983. Osmotic sensitivity of fungal variants resistant to dicarboximide fungicides. Trans. Br. Mycol. Soc. 80:327-331.

Billard, A., Fillinger, S., Leroux, P., Lachaise, H., Beffa, R., and Debieu, D. 2012. Strong resistance to the fungicide fenhexamid entails a fitness cost in Botrytis cinerea, as shown by comparisons of isogenic strains. Pest Manage. Sci. 68:684-691.

Buchenauer, H. 1987. Mechanism of action of triazolyl fungicides and related compounds. Pages 205-232 in: Modern Selective Fungicides: Properties, Applications, Mechanisms of Action. $\mathrm{H}$. Lyr in cooperation with $\mathrm{H}$. Buchenhauer, eds. Longman Scientific and Technical, New York

Chi, M.-H., Park, S.-Y., and Lee, Y.-H. 2009. A quick and safe method for fungal DNA extraction. Plant Pathol. J. 25:108-111.

Chin, K., Chavaillaz, D., Kaesbohrer, M., Staub, T., and Felsenstein, F. 2001. Characterizing resistance risk of Erysiphe graminis f. sp. tritici to strobilurins. Crop Prot. 20:87-96.

De Guido, M., De Miccolis Angelini, R., Pollastro, S., Santomauro, A., and Faretra, F. 2007. Selection and genetic analysis of laboratory mutants of Botryotinia fuckeliana resistant to fenhexamid. J. Plant Pathol. 89: 203-210.

Elad, Y., Yunis, H., and Katan, T. 1992. Multiple fungicide resistance to benzimidazoles, dicarboximides and diethofencarb in field isolates of $\mathrm{Bo}$ trytis cinerea in Israel. Plant Pathol. 41:41-46.

Fernández-Ortuño, D., Chen, F., and Schnabel, G. 2012. Resistance to pyraclostrobin and boscalid in Botrytis cinerea isolates from strawberry fields in the Carolinas. Plant Dis. 96:1198-1203.

Fernández-Ortuño, D., Grabke, A., Bryson, P. K., Amiri, A., Peres, N. A., and Schnabel, G. 2014. Fungicide resistance profiles in Botrytis cinerea from strawberry fields of seven southern US states. Plant Dis. 98:825-833.

Fernández-Ortuño, D., Grabke, A., Li, X., and Schnabel, G. 2015. Independent emergence of resistance to seven chemical classes of fungicides in Botrytis cinerea. Phytopathology 105:424-432.

Fillinger, S., Ajouz, S., Nicot, P. C., Leroux, P., and Bardin, M. 2012. Functional and structural comparison of pyrrolnitrin- and iprodione-induced modifications in the class III histidine-kinase Bos1 of Botrytis cinerea. PLoS One 7:e42520.

Fillinger, S., Leroux, P., Auclair, C., Barreau, C., Al Haji, C., and Debieu, D. 2008. Genetic analysis of fenhexamid-resistant field isolates of the phytopathogenic fungus Botrytis cinerea. Antimicrob. Agents Chemother. 52:3933-3940

Fujimura, M., Ochiai, N., Oshima, M., Motoyama, T., Ichiishi, A., Usami, R., Horikoshi, K., and Yamaguchi, I. 2003. Putative homologs of SSK22 MAPKK kinase and PBS2 MAPK kinase of Saccharomyces cerevisiae encoded by $o s-4$ and $o s-5$ genes for osmotic sensitivity and fungicide resistance in Neurospora crassa. Biosci. Biotechnol. Biochem. 67:186-191.

Giesbert, S., Schumacher, J., Kupas, V., Espino, J., Segmüller, N., Haeuser-Hahn, I., Schreier, P., and Tudzynski, P. 2012. Identification of pathogenesisassociated genes by T-DNA-mediated insertional mutagenesis in Botrytis cinerea: A type 2A phosphoprotein phosphatase and an SPT3 transcription factor have significant impact on virulence. Mol. Plant-Microbe Interact. 25: 481-495.

Hahn, M., Plesken, C., Leroch, M., Düker, A., Rupp, S., Weber, R., Dehne, H., Deising, B., Fraaije, U., and Gisi, D. 2014. Multiple fungicide resistance and genetic diversity of Botrytis spp. in German strawberry fields. Modern fungicides and antifungal compounds VII. Pages 129-134 in: Proc. 17th Int. Reinhardsbrunn Symp. Friedrichroda, Germany.

Hamada, M. S., Yin, Y., and Ma, Z. 2011. Sensitivity to iprodione, difenoconazole and fludioxonil of Rhizoctonia cerealis isolates collected from wheat in China. Crop Prot. 30:1028-1033.

Heller, J., and Tudzynski, P. 2011. Reactive oxygen species in phytopathogenic fungi: Signaling, development, and disease. Annu. Rev. Phytopathol. 49: 369-390

Kretschmer, M., Leroch, M., Mosbach, A., Walker, A.-S., Fillinger, S., Mernke, D., Schoonbeek, H.-J., Pradier, J.-M., Leroux, P., and De Waard, M. A. 2009. Fungicide-driven evolution and molecular basis of multidrug resistance in field populations of the grey mould fungus Botrytis cinerea. PLoS Pathog. 5:e1000696.

Latorre, B. A., and Torres, R. 2012. Prevalence of isolates of Botrytis cinerea resistant to multiple fungicides in Chilean vineyards. Crop Prot. 40:49-52.

Legard, D., Xiao, C., Mertely, J., and Chandler, C. 2001. Management of Botrytis fruit rot in annual winter strawberry using captan, thiram, and iprodione. Plant Dis. 85:31-39.

Leroch, M., Kretschmer, M., and Hahn, M. 2011. Fungicide resistance phenotypes of Botrytis cinerea isolates from commercial vineyards in South West Germany. J. Phytopathol. 159:63-65.

Leroch, M., Plesken, C., Weber, R. W., Kauff, F., Scalliet, G., and Hahn, M. 2013. Gray mold populations in German strawberry fields are resistant to multiple fungicides and dominated by a novel clade closely related to Botrytis cinerea. Appl. Environ. Microbiol. 79:159-167.

Leroux, P., Fritz, R., Debieu, D., Albertini, C., Lanen, C., Bach, J., Gredt, M., and Chapeland, F. 2002. Mechanisms of resistance to fungicides in field strains of Botrytis cinerea. Pest Manage. Sci. 58:876-888.

Leroux, P., Gredt, M., Leroch, M., and Walker, A.-S. 2010. Exploring mechanisms of resistance to respiratory inhibitors in field strains of Botrytis cinerea, the causal agent of gray mold. Appl. Environ. Microbiol. 76: 6615-6630.

Leroux, P., and Walker, A.-S. 2013. Activity of fungicides and modulators of membrane drug transporters in field strains of Botrytis cinerea displaying multidrug resistance. Eur. J. Plant Pathol. 135:683-693.

Li, H., and Xiao, C. 2008. Characterization of fludioxonil-resistant and pyrimethanil-resistant phenotypes of Penicillium expansum from apple. Phytopathology 98:427-435.

Li, X., Fernández-Ortuño, D., Chen, S., Grabke, A., Luo, C.-X., Bridges, W. C., and Schnabel, G. 2014a. Location-specific fungicide resistance profiles and evidence for stepwise accumulation of resistance in Botrytis cinerea. Plant Dis. 98:1066-1074

Li, X., Fernández-Ortuño, D., Grabke, A., and Schnabel, G. 2014b. Resistance to fludioxonil in Botrytis cinerea isolates from blackberry and strawberry. Phytopathology 104:724-732.

Lim, T., Pryor, B., Morgan, D., and Michailides, T. 2003. Sensitivity to iprodione, vinclozolin, and tebuconazole and characters of iprodione-resistant isolates of Alternaria spp. from pistachio. (Abstr.) Phytopathology 93:S128.

Ma, Z., Luo, Y., and Michailides, T. J. 2001. Resistance of Botryosphaeria dothidea from pistachio to iprodione. Plant Dis. 85:183-188.

Ma, Z., Yan, L., Luo, Y., and Michailides, T. J. 2007. Sequence variation in the two-component histidine kinase gene of Botrytis cinerea associated with resistance to dicarboximide fungicides. Pestic. Biochem. Physiol. 88:300-306.

MacKenzie, S., and Peres, N. 2012. Use of leaf wetness and temperature to time fungicide applications to control anthracnose fruit rot of strawberry in Florida. Plant Dis. 96:522-528.

Malandrakis, A. A., Vattis, K. N., Doukas, E. G., and Markoglou, A. N. 2013. Effect of phenylpyrrole-resistance on fitness parameters and ochratoxin production in Aspergillus carbonarius. Int. J. Food Microbiol. $165: 287-294$

Markoglou, A. N., Doukas, E. G., and Ziogas, B. N. 2008. Phenylpyrroleresistance and aflatoxin production in Aspergillus parasiticus Speare. Int. J. Food Microbiol. 127:268-275. 
Mosbach, A., Leroch, M., Mendgen, K. W., and Hahn, M. 2011. Lack of evidence for a role of hydrophobins in conferring surface hydrophobicity to conidia and hyphae of Botrytis cinerea. BMC Microbiol. 11:10.

Pavan, W., Fraisse, C., and Peres, N. 2011. Development of a web-based disease forecasting system for strawberries. Comput. Electron. Agric. 75:169-175.

Parnell, S., Gilligan, C., and Van den Bosch, F. 2005. Small-scale fungicide spray heterogeneity and the coexistence of resistant and sensitive pathogen strains. Phytopathology 95:632-639.

Petsikos-Panayotarou, N., Markellou, E., Kalamarakis, A., Kyriakopoulou, D., and Malathrakis, N. 2003. In vitro and in vivo activity of cyprodinil and pyrimethanil on Botrytis cinerea isolates resistant to other botryticides and selection for resistance to pyrimethanil in a greenhouse population in Greece. Eur. J. Plant Pathol. 109:173-182.

Prins, T. W., Tudzynski, P., von Tiedemann, A., Tudzynski, B., Ten Have, A., Hansen, M. E., Tenberge, K., and van Kan, J. A. 2000. Infection strategies of Botrytis cinerea and related necrotrophic pathogens. Pages 33-64 in: Fungal Pathology. Springer Dordrecht, the Netherlands.

Raposo, R., Delcan, J., Gomez, V., and Melgarejo, P. 1996. Distribution and fitness of isolates of Botrytis cinerea with multiple fungicide resistance in Spanish greenhouses. Plant Pathol. 45:497-505.

Saito, S., Cadle-Davidson, L., and Wilcox, W. F. 2014. Selection, fitness, and control of grape isolates of Botrytis cinerea variably sensitive to fenhexamid. Plant Dis. 98:233-240.

Schouten, A., Tenberge, K. B., Vermeer, J., Stewart, J., Wagemakers, L., Williamson, B., and Van Kan, J. A. 2002. Functional analysis of an extracellular catalase of Botrytis cinerea. Mol. Plant Pathol. 3:227-238.
Temme, N., and Tudzynski, P. 2009. Does Botrytis cinerea ignore H2O2induced oxidative stress during infection? Characterization of Botrytis activator protein 1. Mol. Plant-Microbe Interact. 22:987-998.

Veloukas, T., Kalogeropoulou, P., Markoglou, A., and Karaoglanidis, G. 2014. Fitness and competitive ability of Botrytis cinerea field isolates with dual resistance to SDHI and QoI fungicides, associated with several $s d h \mathrm{~B}$ and the cytb G143A mutations. Phytopathology 104:347-356.

Weber, R. W. 2011. Resistance of Botrytis cinerea to multiple fungicides in northern German small-fruit production. Plant Dis. 95:1263-1269.

Wilcox, W., and Seem, R. 1994. Relationship between strawberry gray mold incidence, environmental variables, and fungicide applications during different periods of the fruiting season. Phytopathology 84 : 264-270.

Yan, L., Yang, Q., Sundin, G. W., Li, H., and Ma, Z. 2010. The mitogen-activated protein kinase kinase BOS5 is involved in regulating vegetative differentiation and virulence in Botrytis cinerea. Fungal Genet. Biol. 47:753-760.

Yourman, L., Jeffers, S., and Dean, R. 2001. Phenotype instability in Botrytis cinerea in the absence of benzimidazole and dicarboximide fungicides. Phytopathology 91:307-315.

Zhao, H., Kim, Y., Huang, L., and Xiao, C. 2010. Resistance to thiabendazole and baseline sensitivity to fludioxonil and pyrimethanil in Botrytis cinerea populations from apple and pear in Washington State. Postharvest Biol. Technol. 56:12-18.

Ziogas, B., Markoglou, A., and Malandrakis, A. 2003. Studies on the inherent resistance risk to fenhexamid in Botrytis cinerea. Eur. J. Plant Pathol. 109: 311-317. 